\title{
Effect of Boron and Sulphur Application on Postharvest Quality after Storage and Reconditioning of Potato (Solanum tuberosum L.)
}

\author{
Mohammad Ali Muthanna*, Anil K. Singh, Rajaneesh Singh and Anupam Tiwari \\ Department of Horticulture, Institute of Agricultural Sciences, Banaras Hindu University, \\ Varanasi- 221005 (U.P.), India \\ *Corresponding author
}

\author{
A B S T R A C T
}

\begin{tabular}{|l|}
\hline Ke y w o r d s \\
Potato, Boron, \\
Sulphur, \\
Postharvest, \\
Storage, \\
Reconditioning. \\
\hline Article Info \\
\hline Accepted: \\
10 September 2017 \\
Available Online: \\
10 October 2017 \\
\hline
\end{tabular}

Present study was carried out at Horticulture Research Farm and Postharvest Laboratory of Department of Horticulture, Institute of Agricultural Sciences, Banaras Hindu University, Varanasi, India. Potato crop was grown 2 years i.e. 2015-16 and 2016-17 in the field. Experiment consisted of control, recommended dose of fertilizer (RDF: $150,80,120 \mathrm{~kg} / \mathrm{ha}$ ), $\mathrm{RDF}+1 \mathrm{~kg} \mathrm{~B}, \mathrm{RDF}+2 \mathrm{~kg} \mathrm{~B}, \mathrm{RDF}+3 \mathrm{~kg} \mathrm{~B}, \mathrm{RDF}+30 \mathrm{~kg} \mathrm{~S}, \mathrm{RDF}+40 \mathrm{~kg} \mathrm{~S}, \mathrm{RDF}+1 \mathrm{~kg}$ $\mathrm{B}+30 \mathrm{~kg} \mathrm{~S}, \mathrm{RFD}+2 \mathrm{~kg} \mathrm{~B}+30 \mathrm{~kg} \mathrm{~S}, \mathrm{RDF}+3 \mathrm{~kg} \mathrm{~B}+30 \mathrm{~kg} \mathrm{~S}, \mathrm{RDF}+1 \mathrm{~kg} \mathrm{~B}+40 \mathrm{~kg} \mathrm{~S}$, $\mathrm{RDF}+2 \mathrm{~kg} \mathrm{~B}+40 \mathrm{~kg} \mathrm{~S}, \mathrm{RDF}+3 \mathrm{~kg} \mathrm{~B}+40 \mathrm{~kg} \mathrm{~S}$ treatments in a Randomized Block Design and replicated thrice. Significant effect of application of boron and sulphur during growing of crop was observed after storage and reconditioning of potato. The treatment $\mathrm{RDF}+2 \mathrm{~kg} \mathrm{~B}+40 \mathrm{~kg} \mathrm{~S}$ showed maximum starch content, specific gravity and total soluble solids after storage and reconditioning. This treatment also exhibited maximum dry matter content after storage and minimum number of sprouted tubers after reconditioning which was significant with application of RDF $+3 \mathrm{~kg} \mathrm{~B}+30 \mathrm{~kg} \mathrm{~S}$.

\section{Introduction}

Potato (Solanum tuberosum L.) is one of the most important Solanaceous tuber crop and grown in more than 125 countries. Potato is consume almost daily by more than a billion people and used as vegetable, stock feed and in industries for manufacturing starch, alcoholic beverages and other processed product (Lutaladio et al., 1995). Its cultivation is mounting strongly in the developing countries accounted for about $31.66 \%$, where the ease of potato cultivation and nutritive content has made it a valuable food security and cash crop for millions of farmers (Anonymous, 2014). Potato tuber contains about $80 \%$ water and rest is dry matter.
Starch is the major component of the dry matter portion accounting for about $70 \%$ of the total solids (Dutt, 2008). It contains starch $(13-16 \%)$, protein $(2 \%)$, total sugars $(0-2 \%)$, fibre $(0.6 \%)$, lipids $(0.1 \%)$, vitamin $\mathrm{C}(31$ $\mathrm{mg} / 100 \mathrm{~g}$ fresh weight) and ash (1-1.5\%) as reported by Shekhawat in 2001 .

Pre-harvest nutrient application affects plant biochemistry and physiology and therefore product quality and storability (Dris et al., 2003). Micro and macro nutrient are known to enhance the quality of the vegetable produce both pre and postharvest in a positive manner (Weston and Barth, 1997). The cultivated 
soils of Varanasi region having emerging deficiency of secondary and micronutrient due to the use of high analysis NPK fertilizers and limited manuring (Singh et al., 2015). Therefore, balanced supply of essential nutrients is necessary for maintaining fertility of soil which helps in better growth, yield and extending postharvest quality of tubers. Boron, an essential micronutrient, present in cellular form in the cell wall (Blevin and Lukaszewski, 1998), plays an important role in maintaining the structural integrity of plant membrane (Pilbeam and Kirkby, 1983) and enhances absorption of calcium ion by improving uptake of it which results in reduce levels of common scab and other tuber diseases (Karlsson and Palta, 2006). Sulphur improves tuber quality through increased content of protein, starch, carotene, vitamin C and gives resistance against Streptomyces scabies and Rhizoctonia solani (Mishra and Srivastava, 2004; Klikocka et al., 2005; Kumar et al., 2007; Klikocka 2009a; Klikocka 2009b). Apart from the application of nutrients, storage $\left(<5^{\circ} \mathrm{C}\right)$ and reconditioning $\left(15-20^{\circ} \mathrm{C}\right)$ is essential for maintaining the level of sugar accumulated in tubers. High level of sugar in potato tubers after cold storage necessitates reconditioning to interconvert sugars into starch and to respire off residual sugars.

Keeping the above content in view, the present study aims to find out the effect of boron and sulphur application in the crop of potato $\mathrm{cv}$. Kufri Lalima on the postharvest quality of tubers after storage and reconditioning.

\section{Materials and Methods}

Present investigation entitled "Effect of boron and sulphur application on postharvest quality after storage and reconditioning of potato" was carried out at Horticulture Research Farm, Department of Horticulture, Institute of
Agricultural Sciences, Banaras Hindu University, Varansi (Uttar Pradesh). Postharvest studies were carried out after storage and reconditioning of tubers in the Postharvest Laboratory of the Department of Horticulture. The district Varanasi is situated $25^{\circ} 10^{\prime}$ North latitude, $83^{\circ} 03^{\prime}$ East longitudes and at an altitude of $123.23 \mathrm{~m}$ above the mean sea level. Uniform sized, disease free tubers of cv. Kufri Lalima having white flesh and deep eyes were taken as planting material in both the years of experiment. Tubers were planted on $20^{\text {th }}$ October of 2015 during $1^{\text {st }}$ year and harvested on $20^{\text {th }}$ February of 2016. $2^{\text {nd }}$ year planting was done on $20^{\text {th }}$ October of 2016 and harvested on $20^{\text {th }}$ February of 2017. Planting was done with a spacing of $20 \mathrm{~cm} \times$ $60 \mathrm{~cm}$ in a plot of $3 \mathrm{~m} \times 1.2 \mathrm{~m}$ size. Thirteen treatments i.e. control, recommended dose of fertilizer (RDF:150,80,120 kg/ha), RDF + 1 $\mathrm{kg} \mathrm{B}, \mathrm{RDF}+2 \mathrm{~kg} \mathrm{~B}, \mathrm{RDF}+3 \mathrm{~kg} \mathrm{~B}, \mathrm{RDF}+$ $30 \mathrm{~kg} \mathrm{~S}, \mathrm{RDF}+40 \mathrm{~kg} \mathrm{~S}, \mathrm{RDF}+1 \mathrm{~kg} \mathrm{~B}+30$ $\mathrm{kg} \mathrm{S}, \mathrm{RFD}+2 \mathrm{~kg} \mathrm{~B}+30 \mathrm{~kg} \mathrm{~S}, \mathrm{RDF}+3 \mathrm{~kg} \mathrm{~B}$ $+30 \mathrm{~kg} \mathrm{~S}, \mathrm{RDF}+1 \mathrm{~kg} \mathrm{~B}+40 \mathrm{~kg} \mathrm{~S}, \mathrm{RDF}+2$ $\mathrm{kg} \mathrm{B}+40 \mathrm{~kg} \mathrm{~S}, \mathrm{RDF}+3 \mathrm{~kg} \mathrm{~B}+40 \mathrm{~kg} \mathrm{~S}$ were taken. Experiment was laid out in a Randomized Block Design and replicated thrice. Nitrogen, phosphorus and potassium were given in the form of urea, single super phosphate and muriate of potash, respectively. Full dose of phosphorus, potassium, boron, sulphur and half dose of nitrogen were applied as basal dose at the time of planting and the rest of nitrogen was applied after 40 days of planting at the time of earthing up. Agronomic practices including regular weeding, earthing up, irrigation and pest control were practiced as and when needed. Fully matured tubers were harvested for further postharvest studies. After harvesting the tubers were cleaned and placed in the cold storage for three months. Reconditioning of tubers was done after storage in the Postharvest Laboratory of the Department of Horticulture for 10 days. Various physiochemical and quality parameters of tubers i.e. 
dry matter, starch, T.S.S., specific gravity, number and weight of diseased and sprouted tubers, weight loss were observed after storage and reconditioning of tubers.

\section{Results and Discussion}

Response of boron, sulphur and their combination significantly affect the weight loss after storage and reconditioning, number and weight of diseased after reconditioning but a non-significant difference was found in the number and weight of diseased tubers after storage due to the effect of boron, sulphur and their combination during both the years of experiment (Table 1). A minimum weight loss $(1.43 \%, 5.07 \%$ and $3.45 \%)$ was recorded with treatment $\mathrm{RDF}+2 \mathrm{~kg} \mathrm{~B}$ during both years of storage and first year of reconditioning of tubers. During second year $\mathrm{RDF}+3 \mathrm{~kg} \mathrm{~B}+30 \mathrm{~kg} \mathrm{~S}(7.50 \%)$ was found to loss minimum weight after reconditioning which was statistically at par with $\mathrm{RDF}+2 \mathrm{~kg}$ B. No diseased tubers were observed during storage condition and a non-significant effect of number and weight of diseased tubers was found among all the treatments due to the effect of boron, sulphur and their combination during first and second year of storage. After reconditioning an increased trend in number and weight of diseased tubers was noticed among all the treatments. Minimum number of diseased tubers $(1.00 \%)$ was found with treatment $\mathrm{RDF}, \mathrm{RDF}+3 \mathrm{~kg} \mathrm{~B}$ and $\mathrm{RDF}+1$ $\mathrm{kg} \mathrm{B}+40 \mathrm{~kg} \mathrm{~S}$ which was significant with $\mathrm{RDF}+2 \mathrm{~kg} \mathrm{~B}, \mathrm{RDF}+30 \mathrm{~kg} \mathrm{~S}, \mathrm{RDF}+40 \mathrm{~kg}$ $\mathrm{S}$, control, $\mathrm{RDF}+1 \mathrm{~kg} \mathrm{~B}+30 \mathrm{~kg} \mathrm{~S}, \mathrm{RDF}+3$ $\mathrm{kg} \mathrm{B}+30 \mathrm{~kg} \mathrm{~S}$ and $\mathrm{RDF}+2 \mathrm{~kg} \mathrm{~B}+40 \mathrm{~kg} \mathrm{~S}$ and during first year of study. Whereas, during second year of reconditioning, RDF + $40 \mathrm{~kg} \mathrm{~S}$ produced minimum number of diseased tubers $(1.00 \%)$ which was statistically at par with treatment control, $\mathrm{RDF}+3 \mathrm{~kg} \mathrm{~B}+30 \mathrm{~kg} \mathrm{~S}$ and $\mathrm{RDF}+3 \mathrm{~kg} \mathrm{~B}+$ $40 \mathrm{~kg} \mathrm{~S}$. The minimum weight $(1.00 \%)$ of diseased tuber was observed in treatment $\mathrm{RDF}, \mathrm{RDF}+3 \mathrm{~kg} \mathrm{~B}$ and $\mathrm{RDF}+1 \mathrm{~kg} \mathrm{~B}+40$
S during first year whereas during second year of reconditioning, minimum weight of diseased tubers $(1.00 \%)$ were recorded under $\mathrm{RDF}+40 \mathrm{~kg} \mathrm{~S}$ which was significant with all the treatments. Loss in weight after digging of potato tubers influenced by various factors i.e. storage temperature, relative humidity of storage area, condition of tubers, stage of harvesting but if all these parameters are taken constant then only nutritive constitution of them is the only affecting factor (Byju et $a l ., 2007)$. The reason behind weight loss may be due to the application of optimum dose of sulphur and boron maintains cell turgidity which results in minimum loss of water and solutes. It is also might be due to under the adequate state of plant sulphur nutrition, is an increase in their resistance and tolerance to abiotic and biotic stresses during storage (Haneklaus et al., 2000). These findings are supported by Sharma et al., (2011) and Pandey et al., (2015) in potato. Minimum number of diseased tubers was found might be due to increase in abiotic stress results inthe tolerance ability and adequate nutrition in plant (Haneklaus et al., 2000).

All the treatments were failed to ecert any any conspicuous effect on number and weight of sprouted tubers during first year of storage and reconditioning, whereas it was significant during second year (Table 2). Minimum number and weight of sprouted tubers $(0.00 \%)$ was recorded in all treatments which was significant with treatment $\mathrm{RDF}+2 \mathrm{~kg} \mathrm{~B}$ during second year of storage. During second year of reconditioning, minimum number of sprouted tubers $(1.00 \%)$ was found in treatment $\mathrm{RDF}+1 \mathrm{~kg} \mathrm{~B}, \mathrm{RDF}+3 \mathrm{~kg} \mathrm{~B}, \mathrm{RDF}$ $+1 \mathrm{~kg} \mathrm{~B}+30 \mathrm{~kg} \mathrm{~S}, \mathrm{RDF}+2 \mathrm{~kg} \mathrm{~B}+40 \mathrm{~kg} \mathrm{~S}$ and minimum weight $(1.00 \%)$ of sprouted tubers was observed in treatment $\mathrm{RDF}+1 \mathrm{~kg}$ $\mathrm{B}, \mathrm{RDF}+40 \mathrm{~kg} \mathrm{~S}, \mathrm{RDF}+3 \mathrm{~kg} \mathrm{~B}, \mathrm{RDF}+1$ $\mathrm{kg} \mathrm{B}+30 \mathrm{~kg} \mathrm{~S}$ and $\mathrm{RDF}+2 \mathrm{~kg} \mathrm{~B}+40 \mathrm{~kg} \mathrm{~S}$ which was statistically at par with RDF, RDF $+2 \mathrm{~kg} \mathrm{~B}, \mathrm{RDF}+30 \mathrm{~kg} \mathrm{~S}, \mathrm{RDF}+3 \mathrm{~kg} \mathrm{~B}+30$ $\mathrm{kg} \mathrm{S}$ and $\mathrm{RDF}+1 \mathrm{~kg} \mathrm{~B}+40 \mathrm{~kg} \mathrm{~S}$. 
Table.1 Effect of boron and sulphur on weight loss, no. of diseased tubers and weight of diseased tubers in potato after storage and reconditioning

\begin{tabular}{|c|c|c|c|c|c|c|c|c|c|c|c|c|}
\hline \multirow[t]{3}{*}{ Treatments } & \multicolumn{4}{|c|}{ Loss of weight (\%) } & \multicolumn{4}{|c|}{ No. of diseased tubers (\%) } & \multicolumn{4}{|c|}{ Weight of diseased tubers $(\%)$} \\
\hline & \multicolumn{2}{|c|}{ Storage } & \multicolumn{2}{|c|}{ Reconditioning } & \multicolumn{2}{|c|}{ Storage } & \multicolumn{2}{|c|}{ Reconditioning } & \multicolumn{2}{|c|}{ Storage } & \multicolumn{2}{|c|}{ Reconditioning } \\
\hline & I year & II year & I year & II year & I year & II year & I year & II year & I year & II year & I year & II year \\
\hline Control & 2.53 & 6.26 & 4.81 & 8.88 & $0.00(1.00)$ & $0.00(1.00)$ & 1.45 & 1.89 & $0.00(1.00)$ & $0.00(1.00)$ & 2.26 & 1.84 \\
\hline RDF (NPK 150:80:120 kg/ha) & 2.61 & 5.80 & 4.76 & 7.90 & $0.00(1.00)$ & $0.00(1.00)$ & 1.00 & 3.29 & $0.00(1.00)$ & $0.00(1.00)$ & 1.00 & 3.49 \\
\hline $\mathrm{RDF}+1 \mathrm{~kg} \mathrm{~B}$ & 2.45 & 5.61 & 4.76 & 8.36 & $0.00(1.00)$ & $0.00(1.00)$ & 1.42 & 2.40 & $0.00(1.00)$ & $0.00(1.00)$ & 1.53 & 2.86 \\
\hline $\mathrm{RDF}+2 \mathrm{~kg} \mathrm{~B}$ & 1.43 & 5.07 & 3.45 & 7.70 & $0.00(1.00)$ & $0.00(1.00)$ & 1.82 & 2.54 & $0.00(1.00)$ & $0.00(1.00)$ & 1.96 & 2.31 \\
\hline $\mathrm{RDF}+3 \mathrm{~kg} \mathrm{~B}$ & 2.37 & 6.61 & 4.34 & 9.56 & $0.00(1.00)$ & $0.00(1.00)$ & 1.00 & 2.90 & $0.00(1.00)$ & $0.00(1.00)$ & 1.00 & 2.87 \\
\hline $\mathrm{RDF}+30 \mathrm{~kg} \mathrm{~S}$ & 3.00 & 5.39 & 5.24 & 7.76 & $0.00(1.00)$ & $0.00(1.00)$ & 2.45 & 3.34 & $0.00(1.00)$ & $0.00(1.00)$ & 2.73 & 3.63 \\
\hline $\mathrm{RDF}+40 \mathrm{~kg} \mathrm{~S}$ & 2.12 & 7.74 & 4.23 & 9.59 & $0.00(1.00)$ & $0.00(1.00)$ & 2.01 & 1.00 & $0.00(1.00)$ & $0.00(1.00)$ & 2.49 & 1.00 \\
\hline $\mathrm{RDF}+1 \mathrm{~kg} \mathrm{~B}+30 \mathrm{~kg} \mathrm{~S}$ & 2.29 & 6.60 & 4.82 & 9.13 & $0.00(1.00)$ & $0.00(1.00)$ & 1.48 & 2.47 & $0.00(1.00)$ & $0.00(1.00)$ & 1.57 & 2.66 \\
\hline RFD + $2 \mathrm{~kg} \mathrm{~B}+30 \mathrm{~kg} \mathrm{~S}$ & 1.79 & 5.57 & 3.73 & 7.96 & $0.00(1.00)$ & $0.00(1.00)$ & 1.50 & 2.79 & $0.00(1.00)$ & $0.00(1.00)$ & 1.42 & 2.11 \\
\hline $\mathrm{RDF}+3 \mathrm{~kg} \mathrm{~B}+30 \mathrm{~kg} \mathrm{~S}$ & 2.54 & 5.23 & 4.76 & 7.50 & $0.00(1.00)$ & $0.00(1.00)$ & 1.56 & 1.72 & $0.00(1.00)$ & $0.00(1.00)$ & 1.36 & 2.44 \\
\hline $\mathrm{RDF}+1 \mathrm{~kg} \mathrm{~B}+40 \mathrm{~kg} \mathrm{~S}$ & 2.70 & 6.19 & 4.75 & 8.64 & $0.00(1.00)$ & $0.00(1.00)$ & 1.00 & 3.28 & $0.00(1.00)$ & $0.00(1.00)$ & 1.00 & 3.19 \\
\hline $\mathrm{RDF}+2 \mathrm{~kg} \mathrm{~B}+40 \mathrm{~kg} \mathrm{~S}$ & 2.79 & 5.46 & 4.97 & 7.89 & $0.00(1.00)$ & $0.00(1.00)$ & 2.37 & 3.04 & $0.00(1.00)$ & $0.00(1.00)$ & 2.45 & 1.95 \\
\hline $\mathrm{RDF}+3 \mathrm{~kg} \mathrm{~B}+40 \mathrm{~kg} \mathrm{~S}$ & 2.81 & 5.25 & 5.07 & 7.78 & $0.00(1.00)$ & $0.00(1.00)$ & 1.46 & 2.06 & $0.00(1.00)$ & $0.00(1.00)$ & 1.60 & 1.85 \\
\hline C.D. at $5 \%$ & 1.36 & 1.48 & 1.62 & 1.83 & NS & NS & 0.49 & 1.24 & NS & $\mathrm{NS}$ & 1.08 & 0.14 \\
\hline
\end{tabular}

Table.2 Effect of boron and sulphur on no. of sprouted tubers, weight of sprouted tubers and dry matter in potato after storage and reconditioning

\begin{tabular}{|c|c|c|c|c|c|c|c|c|c|c|c|c|}
\hline \multirow[t]{3}{*}{ Treatments } & \multicolumn{4}{|c|}{ No. of sprouted tubers (\%) } & \multicolumn{6}{|c|}{ Weight of sprouted tubers (\%) } & \multirow{2}{*}{\multicolumn{2}{|c|}{$\begin{array}{c}\text { Dry matter (\%) } \\
\text { Reconditioning } \\
\end{array}$}} \\
\hline & \multicolumn{2}{|c|}{ Storage } & \multicolumn{2}{|c|}{ Reconditioning } & \multicolumn{2}{|c|}{ Storage } & \multicolumn{2}{|c|}{ Reconditioning } & \multicolumn{2}{|c|}{ Storage } & & \\
\hline & I year & II year & I year & II year & I year & II year & I year & II year & I year & II year & I year & II year \\
\hline Control & $0.00(1.00)$ & 0.00 & 0.00 & 1.00 & $0.00(1.00)$ & 0.00 & 1.00 & 1.00 & 19.83 & 22.10 & 18.21 & 20.34 \\
\hline RDF (NPK 150:80:120 kg/ha) & $0.00(1.00)$ & 0.00 & 0.00 & 1.77 & $0.00(1.00)$ & 0.00 & 1.00 & 2.04 & 16.68 & 21.54 & 16.66 & 21.05 \\
\hline $\mathrm{RDF}+1 \mathrm{~kg} \mathrm{~B}$ & $0.00(1.00)$ & 0.00 & 0.00 & 1.00 & $0.00(1.00)$ & 0.00 & 1.00 & 1.00 & 18.80 & 22.36 & 16.42 & 19.47 \\
\hline $\mathrm{RDF}+2 \mathrm{~kg} \mathrm{~B}$ & $0.00(1.00)$ & 2.57 & 0.00 & 2.92 & $0.00(1.00)$ & 2.30 & 1.00 & 3.46 & 18.52 & 23.01 & 17.90 & 21.16 \\
\hline $\mathrm{RDF}+3 \mathrm{~kg} \mathrm{~B}$ & $0.00(1.00)$ & 0.00 & 2.78 & 1.00 & $0.00(1.00)$ & 0.00 & 2.03 & 1.00 & 16.59 & 25.68 & 16.42 & 22.38 \\
\hline $\mathrm{RDF}+30 \mathrm{~kg} \mathrm{~S}$ & $0.00(1.00)$ & 0.00 & 0.00 & 1.97 & $0.00(1.00)$ & 0.00 & 1.00 & 2.09 & 18.04 & 23.21 & 18.35 & 20.94 \\
\hline $\mathrm{RDF}+40 \mathrm{~kg} \mathrm{~S}$ & $0.00(1.00)$ & 0.00 & 0.00 & 2.21 & $0.00(1.00)$ & 0.00 & 1.00 & 1.00 & 15.29 & 20.49 & 16.10 & 21.27 \\
\hline $\mathrm{RDF}+1 \mathrm{~kg} \mathrm{~B}+30 \mathrm{~kg} \mathrm{~S}$ & $0.00(1.00)$ & 0.00 & 0.00 & 1.00 & $0.00(1.00)$ & 0.00 & 1.00 & 1.00 & 21.13 & 24.08 & 17.43 & 22.20 \\
\hline RFD + $2 \mathrm{~kg} \mathrm{~B} \mathrm{+} 30 \mathrm{~kg} \mathrm{~S}$ & $0.00(1.00)$ & 0.00 & 3.33 & 3.01 & $0.00(1.00)$ & 0.00 & 2.30 & 10.34 & 17.48 & 22.87 & 16.92 & 20.62 \\
\hline $\mathrm{RDF}+3 \mathrm{~kg} \mathrm{~B}+30 \mathrm{~kg} \mathrm{~S}$ & $0.00(1.00)$ & 0.00 & 0.00 & 3.72 & $0.00(1.00)$ & 0.00 & 1.00 & 3.82 & 14.88 & 20.17 & 16.17 & 21.24 \\
\hline $\mathrm{RDF}+1 \mathrm{~kg} \mathrm{~B}+40 \mathrm{~kg} \mathrm{~S}$ & $0.00(1.00)$ & 0.00 & 0.00 & 3.88 & $0.00(1.00)$ & 0.00 & 1.00 & 3.90 & 16.26 & 21.65 & 17.42 & 19.89 \\
\hline $\mathrm{RDF}+2 \mathrm{~kg} \mathrm{~B}+40 \mathrm{~kg} \mathrm{~S}$ & $0.00(1.00)$ & 0.00 & 3.70 & 1.00 & $0.00(1.00)$ & 0.00 & 2.23 & 1.00 & 17.82 & 23.28 & 20.62 & 22.90 \\
\hline $\mathrm{RDF}+3 \mathrm{~kg} \mathrm{~B}+40 \mathrm{~kg} \mathrm{~S}$ & $0.00(1.00)$ & 0.00 & 0.00 & 3.98 & $0.00(1.00)$ & 0.00 & 0.00 & 18.27 & 19.55 & 18.32 & 18.66 & 21.24 \\
\hline C.D. at $5 \%$ & $\mathrm{NS}$ & 2.57 & NS & 1.56 & $\mathrm{NS}$ & 2.30 & NS & 3.86 & 2.61 & 2.81 & 1.96 & 2.56 \\
\hline
\end{tabular}


Int.J.Curr.Microbiol.App.Sci (2017) 6(10): 1028-1035

Table.3 Effect of boron and sulphur on starch, specific gravity and TSS in potato after storage and reconditioning

\begin{tabular}{|c|c|c|c|c|c|c|c|c|c|c|c|c|}
\hline \multirow[t]{3}{*}{ Treatments } & \multicolumn{4}{|c|}{$\operatorname{Starch}(\%)$} & \multicolumn{4}{|c|}{ Specific gravity (\%) } & \multicolumn{4}{|c|}{ T.S.S. (\%) } \\
\hline & \multicolumn{2}{|c|}{ Storage } & \multicolumn{2}{|c|}{$\begin{array}{c}\text { Reconditionin } \\
\mathrm{g}\end{array}$} & \multicolumn{2}{|c|}{ Storage } & \multicolumn{2}{|c|}{$\begin{array}{c}\text { Reconditionin } \\
\mathrm{g}\end{array}$} & \multicolumn{2}{|c|}{ Storage } & \multicolumn{2}{|c|}{$\begin{array}{c}\text { Reconditionin } \\
\mathrm{g}\end{array}$} \\
\hline & $\begin{array}{l}\text { I } \\
\text { year }\end{array}$ & $\begin{array}{l}\text { II } \\
\text { year }\end{array}$ & $\begin{array}{l}\text { I } \\
\text { year }\end{array}$ & $\begin{array}{l}\text { II } \\
\text { year }\end{array}$ & $\begin{array}{l}\text { I } \\
\text { year }\end{array}$ & $\begin{array}{l}\text { II } \\
\text { year }\end{array}$ & $\begin{array}{l}\text { I } \\
\text { year }\end{array}$ & $\begin{array}{l}\text { II } \\
\text { year }\end{array}$ & $\begin{array}{l}\text { I } \\
\text { year }\end{array}$ & $\begin{array}{l}\text { II } \\
\text { year }\end{array}$ & $\begin{array}{l}\text { I } \\
\text { year }\end{array}$ & $\begin{array}{l}\text { II } \\
\text { year }\end{array}$ \\
\hline Control & 13.67 & 15.69 & 12.23 & 14.14 & 1.07 & 1.08 & 1.08 & 1.08 & 7.17 & 5.50 & 6.50 & 5.43 \\
\hline $\begin{array}{lll}\text { RDF } & \text { (NPK } & 150: 80: 120 \\
\mathrm{~kg} / \mathrm{ha}) & & \end{array}$ & 10.82 & 15.20 & 10.86 & 14.76 & 1.06 & 1.08 & 1.06 & 1.08 & 6.50 & 5.33 & 7.17 & 5.00 \\
\hline $\mathrm{RDF}+1 \mathrm{~kg} \mathrm{~B}$ & 12.76 & 15.93 & 10.65 & 13.35 & 1.07 & 1.09 & 1.06 & 1.07 & 6.83 & 5.50 & 7.57 & 5.07 \\
\hline $\mathrm{RDF}+2 \mathrm{~kg} \mathrm{~B}$ & 12.51 & 16.51 & 11.96 & 14.87 & 1.07 & 1.09 & 1.06 & 1.08 & 7.00 & 6.00 & 7.33 & 4.90 \\
\hline $\mathrm{RDF}+3 \mathrm{~kg} \mathrm{~B}$ & 10.79 & 16.75 & 10.65 & 15.95 & 1.06 & 1.07 & 1.06 & 1.09 & 6.83 & 5.83 & 6.50 & 5.37 \\
\hline $\mathrm{RDF}+30 \mathrm{~kg} \mathrm{~S}$ & 12.08 & 16.68 & 12.36 & 14.67 & 1.07 & 1.09 & 1.07 & 1.08 & 7.00 & 6.00 & 7.67 & 5.17 \\
\hline $\mathrm{RDF}+40 \mathrm{~kg} \mathrm{~S}$ & 9.64 & 14.27 & 10.36 & 14.96 & 1.05 & 1.08 & 1.06 & 1.09 & 6.50 & 5.00 & 7.50 & 5.27 \\
\hline $\mathrm{RDF}+1 \mathrm{~kg} \mathrm{~B}+30 \mathrm{~kg} \mathrm{~S}$ & 11.89 & 17.46 & 11.55 & 15.79 & 1.06 & 1.09 & 1.06 & 1.08 & 7.17 & 5.67 & 7.00 & 5.83 \\
\hline RFD + $2 \mathrm{~kg} \mathrm{~B} \mathrm{+} 30 \mathrm{~kg} \mathrm{~S}$ & 11.59 & 16.38 & 11.24 & 14.39 & 1.06 & 1.09 & 1.06 & 1.08 & 7.00 & 5.67 & 7.17 & 5.17 \\
\hline $\mathrm{RDF}+3 \mathrm{~kg} \mathrm{~B}+30 \mathrm{~kg} \mathrm{~S}$ & 9.27 & 13.98 & 10.43 & 14.93 & 1.05 & 1.08 & 1.05 & 1.08 & 6.83 & 5.33 & 7.50 & 5.67 \\
\hline $\mathrm{RDF}+1 \mathrm{~kg} \mathrm{~B}+40 \mathrm{~kg} \mathrm{~S}$ & 10.50 & 15.30 & 11.47 & 13.73 & 1.06 & 1.08 & 1.06 & 1.07 & 6.83 & 5.67 & 7.50 & 5.93 \\
\hline $\mathrm{RDF}+2 \mathrm{~kg} \mathrm{~B}+40 \mathrm{~kg} \mathrm{~S}$ & 14.80 & 18.88 & 14.38 & 16.41 & 1.08 & 1.09 & 1.07 & 1.09 & 7.40 & 5.67 & 7.84 & 6.00 \\
\hline $\mathrm{RDF}+3 \mathrm{~kg} \mathrm{~B}+40 \mathrm{~kg} \mathrm{~S}$ & 13.43 & 12.33 & 12.64 & 14.93 & 1.07 & 1.10 & 1.07 & 1.08 & 7.33 & 5.33 & 7.83 & 5.03 \\
\hline C.D. at $5 \%$ & 2.62 & 2.50 & 1.74 & 2.27 & 0.01 & 0.01 & NS & 0.01 & 0.90 & NS & 1.33 & 0.80 \\
\hline
\end{tabular}


After storage and reconditioning of tubers, the dry matter content was positively influenced by the application of Sulphur, boron and their combined application along with recommended fertilizer doses (RDF).An increase in dry matter content was observed after recondition of tubers. Maximum dry matter $(21.13 \%)$ was found in treatment RDF $+1 \mathrm{~kg} \mathrm{~B}+30 \mathrm{~kg} \mathrm{~S}$ during first year; whereas, during second year of storage it was found maximum (25.68\%) with treatment $\mathrm{RDF}+3$ $\mathrm{kg} \mathrm{B}$. After reconditioning, $\mathrm{RDF}+2 \mathrm{~kg} \mathrm{~B}+$ $40 \mathrm{~kg} \mathrm{~S}$ was found to contain maximum dry matter $(20.62 \%$ and $22.90 \%)$ which was statistically at par with RDF $+3 \mathrm{~kg} \mathrm{~B}+40 \mathrm{~kg}$ $\mathrm{S}$ in both the years of experiment. Undesirable sprouting reduces the weight, the nutritional and processing quality of tubers during potatoes storage (Delaplace et al., 2008). Sprouting affects the internal composition of the tuber and destruction of edible material and changes in nutritional quality (De Carvalho and da Fonseca, 2006). As a result it reduces the weight of tubers (Burton, 1951). Dry matter content increases after reconditioning of tubers that increases the quality of tubers due to the effect of boron and sulphur. Singh et al., (1995) also suggest the positive effect of boron and sulphur on dry matter content. Mondal et al., (2002) had the similar findings in the green gram.

A significant effect on starch content was found due to the application of boron, sulphur and their combination during the storage and reconditioning of tubers (Table 3 ). $\mathrm{RDF}+2$ $\mathrm{kg} \mathrm{B}+40 \mathrm{~kg} \mathrm{~S}$ was found to contain maximum starch content $(14.80 \%)$ which was statistically at par with RDF $+2 \mathrm{~kg} \mathrm{~B}$ during both years of storage and statistically at par with $\mathrm{RDF}+3 \mathrm{~kg} \mathrm{~B}+40 \mathrm{~kg} \mathrm{~S}$ during both years of reconditioning. Specific gravity was significantly influenced by the application of boron, Sulphur and their combination except the first year of reconditioning. In storage condition, specific gravity was found maximum $(1.08 \%)$ with treatment $\mathrm{RDF}+2$ $\mathrm{kg} \mathrm{B}+40 \mathrm{~kg} \mathrm{~S}$ during first year and RDF +3 $\mathrm{kg} \mathrm{B}+40 \mathrm{~kg} \mathrm{~S}(1.10 \%)$ during second year; both was statistically at par with $\mathrm{RDF}+1 \mathrm{~kg}$ $\mathrm{B}, \mathrm{RDF}+2 \mathrm{~kg} \mathrm{~B}$ and RDF $+30 \mathrm{~kg} \mathrm{~S}$. After reconditioning, treatment control was found to contain maximum specific gravity $(1.08 \%)$ during first year and $\mathrm{RDF}+3 \mathrm{~kg} \mathrm{~B}, \mathrm{RDF}+40$ $\mathrm{kg} \mathrm{S}$ and $\mathrm{RDF}+2 \mathrm{~kg} \mathrm{~B}+40 \mathrm{~kg} \mathrm{~S}$ during second year (1.09\%). RDF $+2 \mathrm{~kg} \mathrm{~B}+40 \mathrm{~kg} \mathrm{~S}$ was recorded maximum T.S.S. content during both years of storage and reconditioning except second year of storage.

A non-significant effect on T.S.S content was found during second year of storage due to the application of boron, sulphur and their combination. $\mathrm{RDF}+2 \mathrm{~kg} \mathrm{~B}+40 \mathrm{~kg} \mathrm{~S}$ was recorded for maximum T.S.S. (7.84\%) during both the year of reconditioning which was statistically at par with RDF $+3 \mathrm{~kg} \mathrm{~B}+40 \mathrm{~kg}$ $\mathrm{S}$ during first year and during second year $(6.00 \%)$, it was statistically at par with RDF + $1 \mathrm{~kg} \mathrm{~B}+40 \mathrm{~kg} \mathrm{~S}$.

There was no findings found regarding to starch content of the tubers which can be influenced by the application of boron and sulphur. In contrast with the finding, Boylan et al., (1991) reported that starch content increases during the early stage development of tomato fruit. There was an increase in the conversion of sucrose into starch with addition of $\mathrm{KCl}$ and further stimulated by $\mathrm{K}^{+}$ ion. A rise in specific gravity is directly affected by dry matter content of tubers which was largely a function of improved growth, translocation of more photosynthates towards sink and consequent accumulation of dry matter in potato tubers Verma and Singh (2012). Similar findings has been also reported by Sharma et al., (2011) and ElFayoumy and El-Gamal (1998). While in case of T.S.S, the increment might be due to hydrolysis of different insoluble constituent like starch, vitamins and proteins; high T.S.S. shows better quality of tubers with superior nutritive value (Pathak and Mitra, 2008). 
Based on the present study, the overall evaluation of boron, sulphur and their combination indicated that the application of boron and sulphur along with recommended dose of fertilizers resulted in better quality and physico-chemical composition of potato tubers. The application of $2 \mathrm{~kg}$ boron and 40 $\mathrm{kg}$ sulphur along with recommended dose of fertilizers found best in dry matter content, starch content, and total soluble solids whereas, having minimum values in number of diseased tubers, number of sprouted tubers during storage and reconditioning. Hence, application of $2 \mathrm{~kg}$ boron and $40 \mathrm{~kg}$ sulphur along with recommended dose of fertilizers could be recommended to enhance number of healthy tubers and postharvest quality of potato, to enhance the farmers earning and to encourage them for potato cropping under indo-gangatic alluvial region of India.

\section{References}

Anonymous, 2014. Area and production of potato in India during 2013-14. Data Year book of National Horticulture Board, Gurgaon (Haryana), India.

Blevins, D.G., and Lukaszewski, K.M. 1998. Boron in plant structure and function. Annual Review of Plant Biology, 49(1): 481-500.

Burton, W.G., 1974. Requirements of the users of ware potatoes. Potato Research, 17(3): 374-409.

Byju, G., Nedunchezhiyan, M., and Naskar, S.K. 2007. Sweet potato response to boron application on an alfisols in the subhumid tropical climate of India. Communications in Soil Science and Plant Analysis, 38(17-18): 2347-2356.

De Carvalho, C.C., and da Fonseca, M.M.R. 2006. Biotransformation of terpenes. Biotechnology Advances, 24(2): 134-142.

Delaplace, P., Brostaux, Y., Fauconnier, M.L. and du Jardin, P. 2008. Potato (Solanum tuberosum L.) tuber physiological age index is a valid reference frame in postharvest ageing studies. Postharvest Biology and Technology, 50(1): 103106.

Dris, R., Niskanen, R., and Jain, S. M. 2003. Crop Management and Postharvest Handling of Horticultural Products. Fruits and Vegetables, Volume II. Science Publishers, Inc.

Dutt, S., 2008. Potato food: an antidote to hunger. Indian Horticulture, 53: 2p.

El-Fayoumy, M.E., and El-Gamal, A.M. 1998. Effects of sulphur application rates on nutrients availability, uptake and potato quality and yield in calcaerous soil. Egyptian Journal of Soil Science, 38(1/4): 271-286.

Haneklaus, S., Bloem, E. and Schnug, E. 2000. Sulphur in agroecosystems. Folia Universitatis Agriculturae Stetinensis, Agricultura, 81: 17-31.

Klikocka, H., 2009a. The Influence of enriched NPK fertilization with $\mathrm{S}, \mathrm{Mg}$ and contained of micronutrients liquid fertilizer Insol 7 on potato tubers yield (Solanum tuberosum L.) and infestation of tubers with Streptomyces scabies and Rhizoctonia solani. J. Elementol., 14(2): 271-288.

Klikocka, H., 2009b. Sulfur supply in polish agriculture. In: Sulfur Metabolism in Plants. Sirko A., De Kok L.J., Haneklaus S., Hawkesford M.J., Rennenberg H., Saito K., Schnug E., Stulen I. (eds). Backhuys Publ., Leiden, the Netherlands, Margraf Publishers, Weikersheim, Germany, 45-48.

Klikocka, H., Haneklaus, S., Bloem, E. and Schnug, E. 2005. Influence of sulfur fertilization on infection of potato tubers with Rhizoctonia solani and Streptomyces scabies. J. Plant Nutr, 28(5): 1-14.

Kumar, P., Pandey, S.K., Singh, B.P., Singh, S.V. and Kumar, D. 2007. Influence of 
source and time of potassium application on potato growth, yield, economics and crisp quality. Potato Res., 50: 1-13.

Lutaladio, N.B., Ewell, P.T. and Kidanemarian, H. 1995. Advances in potato research in eastern and central Africa. In: Root Crops and Poverty Alleviation. Proceeding of the $6^{\text {th }}$ triennial symposium of the International Society of Tropical Root Crops-Africa branch (ISTRC-AB) 22-28 October, Lilongwe, ISTRC. pp. 555-561.

Mishra, K.K., and Srivastava, J.S. 2004. Soil amendments to control common scab of potato. Potato Res., 47: 101-109.

Mondal, S.S., Mandal, S. and Sarkar, S. 2002. Response of potato (Solanum tuberosum) to sulphur bearing fertilizers and their residual effect on greengram (Phaseolus radiatus) in lower Gangetic plains of West Bengal. Indian Journal of Agronomy, 47(2): 181-186.

Ozgen, S., Karlsson, B.H. and Palta, J.P. 2006. Response of potatoes (cv. Russet Burbank) to supplemental calcium applications under field conditions: tuber calcium, yield and incidence of internal brown spot. American Journal of Potato Research, 83(2): 195-204.

Pandey, M., Chaturvedi, B.K., Singh, S. and Shukla, P.K. 2015. Status and response of sulphur in alluvial soils for higher yield of potato. Journal of the Indian Society of Soil Science, 63(1): 107-111.

Pathak, P.K., and Mitra, S.K. 2008. Effect of phosphorus, potassium, sulphur and boron on litchi. Indian Journal of Horticulture, 65(2): 137-140.
Pilbeam, D.J., and Kirkby, E.A. 1983. The physiological role of boron in plants. Journal of Plant Nutrition, 6(7): 563-582.

Sharma, D.K., Kushwah, S.S., Nema, P.K. and Rathore, S.S. 2011. Effect of sulphur on yield and quality of potato (Solanum tuberosum L.). International Journal of Agricultural Research, 6(2): 143-148.

Shekhawat, G.S., 2001. Potato production, utilization and marketing in India. Journal of the Indian Potato Association, 28(2-4): 185-93.

Singh, J.P., and Srivastava, O.P. 1995. Processing and nutritive qualities of potato tubers as affected by fertilizer nutrients and sulphur application. Journal of the Indian Potato Association, 9(3): 115-119.

Singh, S.K., Dey, P., Singh, S., Sharma, P.K., Singh, Y.V., Latare, A.M., Singh, C.M., Kumar, D., Kumar, O., Yadav, S.N. and Verma, S.S. 2015. Emergence of boron and sulphur deficiency in soils of Chandauli, Mirzapur, Sant Ravidas Nagar and Varanasi districts of eastern Uttar Pradesh. Journal of the Indian Society of Soil Science, 63(2): 200-208.

Verma, D., and Singh, H. 2012. Response of varying levels of potassium and sulphur on yield and uptake of nutrients by onion. Annals of Plant and Soil Research, 14: 143-146.

Weston, L.A., and Barth, M.M. 1997. Preharvest factors affecting postharvest quality of vegetables. Hortscience, 32(5): 812-816.

\section{How to cite this article:}

Mohammad Ali Muthanna, Anil K. Singh, Rajaneesh Singh and Anupam Tiwari. 2017. Effect of Boron and Sulphur Application on Postharvest Quality after Storage and Reconditioning of Potato (Solanum tuberosum L.). Int.J.Curr.Microbiol.App.Sci. 6(10): 1028-1035. doi: https://doi.org/10.20546/ijcmas.2017.610.124 